\title{
Board Independence and Company Performance in East Africa
}

\author{
David Namanya* Grace Musiime Chris Muganga \\ College of Business Management Sciences (CoBAMS), Makerere University \\ P.O. Box 7062, Kampala, Uganda
}

The research is self-financed by the author

Abstract

Purpose: The main aim of this study was to examine influence of board independence on financial performance of listed companies in the East African Community (EAC) by examining the influence of board independence on performance of EAC's listed companies and compare the influence of board independence on company's financial performance before and after the operationalisation of the EAC- Common Market in 2010 to make recommendations on how board independence can enhance of hinder a company's financial performance Design/Methodology/Approach: We adopted a positivist paradigm in a quantitative analysis using nonprobability sampling to select forty-two EAC listed companies. We developed hypothesises basing on secondary data from databases (DataStream, Eikon, Mint Global Bureau Van Dijk) and company's annual reports. SPSS was used to carry out regression diagnostic test and generate descriptive statistics, correlation, and regression results. Findings and Recommendation: Our findings indicated that to some extent board independence had a statistically significant influence on company financial performance measured by RoA, RoE, TbQ but not PeR. Secondly; we also discovered some negligible changes in board independence for most listed companies for the period before and after operationalisation of the EAC - Common Market. Based on our inconclusive statistical results and the extant literature review, we recommend that EAC listed companies adopt a code of best practice that emphasises an increase in board independence.

Keywords: Board Independence, Regional Economic Integration, Financial Performance.

DOI: $10.7176 /$ RJFA/12-12-01

Publication date: June $30^{\text {th }} 2021$

\subsection{INTRODUCTION}

A board is said to be independent if it composed of majority non-executive directors with no material interests in the business of an organisation other than their directorship. This study adopted the proportion of outside directors to total directors as the measure of board independence (Barontini \& Caprio 2006; Moldasheva 2015; Tshipa 2015; Youssef \& Bayoumi 2015). According to CMA, K (2002), a board is said to be independent if its membership of non-executive directors is more than fifty percent of the total board membership. The main significance of board independence lies in better monitoring of the company which mitigates principal-agent conflicts (Jensen, Michael C \& Meckling 1976). Hence, most corporate governance codes and good practices, require the board to be composed of both inside directors (executive directors) and non-executive directors (Cadbury 1992; CMA, K 2002; OECD 1999, 2004, 2015).The main relationship between board independence and company performance is based on the assumption that board independence results in improved company monitoring and control, promotes better decision-making and greater efficiency in the allocation of a company resources, increase productivity, and which is likely to increase company financial performance (Katto et al, 2014; Peters \& Bagshaw 2014).

According to Fama and Jensen (1983), having a majority of independent, non-executive directors on the board enhances the board's ability to create value for the company and minimises fraud on the part of the executive management. This will undoubtedly reduce the company's operating risks. Moreover, Forker (1992) claimed that having independent non-executive directors on company boards improves the quality of financial disclosure, thus enhancing investor confidence which improves company's bottom-line. This view was maintained by Mattingly (2004)'s suggestion that outside directors exercise a higher level of monitoring and control over the management's activities, because they are not part of the company's day-to-day operations. Since they are able to improved monitoring function, it improves company's financial performance (Fama \& Jensen 1983; Porter 2008).

The board requires a high level of independence for the company to be monitored effectively and achieve better financial performance (Bhagat, S. \& Bolton 2008; Haniffa, R. \& Hudaib 2006). Youssef and Bayoumi (2015) studied the relationship between board independence and banks' financial performance in Egypt and discovered a significant relationship between board independence and banks financial performance. Soliman, Ragab and Eldin (2014) used a sample of Egyptian listed companies and identified a positive relationship between board independence and company financial performance. A related was carried out in South Africa by Tshipa (2015) and it was discovered that the presence of independent non-executive directors positively influenced the companies' financial performance. Siwadi, Miruka and Ogutu (2015), also examined the influence of board independence on company financial performance in Zimbabwe and found a significant positive relationship. Agyekum, Otchere and Bedi (2014), used Ghana Stock Exchange listed companies to examine the relationship between corporate 
governance and company performance. Being the first study in Ghana to test the relationship between corporate governance and company performance, using the cash flow approach and the modified Jones model in estimating total accruals as a measure of earnings management, the study discovered a significant relationship between board independence and company financial performance (Agyekum, Otchere \& Bedi 2014).

According to Cadbury Report (1992), the presence of non-executive directors on the board enhances company performance. This proposition was adopted by all Capital Market Authorities (CMA) in East Africa in their corporate governance framework (CMA Kenya 2015). Consequently, all listed companies on the Nairobi Security Exchange (NSE) are required to a third of non-executive directors on every board / governing council to ensure proper checks and balances within organisations while protecting all stakeholders interests (Petrovic 2008). Additionally, Gitundu et al. (2016), study in Kenya established that independent non-executive directors positively influenced the company efficiency, while Morekwa Nyamongo and Temesgen (2013) contend that the existence of independent board of directors enhances the performance of banks in Kenya.

On the centrally, Agrawal and Knoeber (1996); Bhagat, S. and Bolton (2008); Klein (1998); Yermack (1996) found an adverse relationship between board independence and company financial performance, while Bhagat, S. and Bolton (2008) discovered that board independence is negatively related with financial performance and castigated companies that increase the number of non-executive directors with the hope of achieving higher financial performance as being misguided. This stance is supported by Hermalin and Weisbach (1991), who suggested that outside directors are only effective at monitoring and disciplining managers of poorly performing companies, not for enhancement of company performance, because the presence of independent non-executive directors only enhances the board's monitoring function which is the only factor that effects company performance. Last but not the least, Fosberg (1989) discovered no relation between a higher percentage of non-executive directors and various company performance measures, while Hermalin and Weisbach (1991) and Laing and Weir (1999) found no significant relationship between board composition and company performance. According to Yermack (1996), the proportion of non-executive directors does not significantly affect company financial performance. Board independence in this study was calculated as the ratio of non-executive directors to total number of directors (Anderson \& Reeb 2003; Barontini \& Caprio 2006).

Company Financial performance

Financial performance is a measurement of company results, policies and processes in monetary terms (Margolis $\&$ Walsh 2001).The commonly used performance measurement in accounting and finance include return on equity, return on assets, profit margin, sales growth etcetera, which measures the extent to which a company achieved her period's financial objectives (El-Shishini 2001). According to Lussier (2011), achievement of financial objectives is influenced the prevailing internal and external risk, this call for stronger internal control systems within an organisation to monitor and control the activities of an organisation by both the executive and non-executive directors. It is thus the responsibility of the company management to identify, analyse and mitigate such risk factors by designing good corporate governance policies that can enable investors to realise their expected return on investment (Shleifer \& Vishny 1997).

According to Jensen, Michael and Meckling (1976), company performance is the foundation for the principal-agent relationship, which is derived from the agreement between principal (shareholder) and agent (manager) giving the agent powers to use company assets to generate profits for the shareholder's wealth maximisation. This forms part of the manager's main task; ensuring that the company achieves good performance outcomes (Feltham \& Xie 1994). Measuring company financial performance therefore helps the principal to evaluate the agent's contribution to the company's profitability over a specified period of time (Wild 1994). Confirmatory to Fama and Jensen (1983), companies' performance depends on agents' decisions. If managers are more motivated to maximise their personal benefits, they are likely to make poor decisions that result in poor company performance. For instance, the management of the defunct Enron and WorldCom put their personal interests before those of their company, which resulted in its calamitous failure (Claessens, S. \& Yurtoglu 2013). Therefore, for a company to achieve maximum profitability, it must have a good corporate governance framework which ensures a degree of altruism in the executive management's decisions (Shleifer \& Vishny 1997). Performance measurements can be broadly categorised in two: (1) accounting based, (2) market based performance measurements.

An accounting-based performance measurement involves the use of the accounting information to assess the extent to which a company has achieved its predetermined performance objectives using the present and past published financial accounting data (Agarwal, Y 2013; Weber et al. 2012). According to Baker and Anderson (2010), in the beginning, profit -based measurement was the commonly used measure of performance, this complemented with introduction of Net Present Value by Fisher (1930) and Internal Rate of return) by Hirshleifer (1958). These two were later improved on by adding on a new valuation technique by Miller and Modigliani (1958, 1961) who postulated a new capital structure model used in company valuation. According to Knight (1998), most traditional accounting-based measures were developed to help in the management's decision-making, accountability and budgetary control activities. Hengartner (2006) posits that accounting-based performance 
measures are strong measures of performance; they provide reliable results, especially during period of economic crisis, and are relatively free from speculation as compared to market-based measures. Furthermore, according to Baker and Anderson (2010), accounting-based performance measures have the advantage of being directly linked to a company's financial survival.

Market performance measurements on the other hand include market-based ratios such as market share, number of customers and the Tobin's q ratio (Kim 2015; Rossi, Nerino \& Capasso 2015; Zagorchev \& Gao 2015) and PeR (Aik, Hassan \& Mohamad 2015; De Aguiar, Pinheiro \& Oyadomari 2014; Shah, Haldar \& Rao 2014). Unlike accounting-based performance measures, market-based measures use market value data to determine company financial performance (Eikelenboom 2005). The main advantage of market-based approaches is that they are less prone to managerial manipulations or creative accounting (Mulsow 2011). Market-based measures of performance are also risk-adjusted, especially where the Capital Asset Pricing Model (CAPM) is used in calculating the company's market value (Mans-Kemp 2014). Hence, it is believed that using market-based ratios like $\mathrm{TbQ}$ provides better measures of performance, which are more reliable, long term-oriented and risk-adjusted (Kim 2015; Li, SL \& Tallman 2011). This study adopted a combination of accounting-based (RoA and RoE) and market-based (TbQ and PeR) to maximise the advantage of each of the methods. These measures have been adopted given their wide usage in previous business finance, corporate governance, finance and company performance researches (AdeBIite 2012; Ansong 2013; Bhagat, S. \& Bolton 2008; Mans-Kemp 2014; Okiro 2014). Aims of the study

The overarching aim of this study is to examine the influence of board independence on the companies' financial performance within the EAC by addressing the following specific objectives:

Examine the influence of board independence on performance of EAC's listed companies

Compare the influence of board independence on company's financial performance before and after the operationalisation of the EAC-Common Market to make recommendations on how board independence can enhance of hinder a company's financial performance

We hope this study will provide new and relevant knowledge about board independence in developing countries in general, and EAC countries in particular. The findings will also help in encouraging economic growth and development by identifying board independence as good corporate governance practices (OECD 1999, 2004, 2015).

\section{LITERATURE REVIEW}

A number of theories have been used in research to explain the relationship between board independence and company financial performance. These include the agency theory, the stakeholders' theory, the resource dependency theory, the legitimacy theory, and the institutional theory.

\subsection{Resource dependency theory}

According to resource dependency theory, the value of any board member is measured by his or her ability to attract and bring in external resources into the company for the benefits of the shareholders (AdeBIite 2012). Hence, companies appoint board members based on their ability to promote the company access to some critical external resources that can enhance company value (Johnson, Daily \& Ellstrand 1996). These resources may include expertise, public influence, networks or influential professionals and industry experts (Abdullah, H \& Valentine 2009). According to Pfeffer and Salancik (2003), recruitment of an external (independent) board member is likely create a favourable linkage between the company and its external environment. Such networks provide a company with new information and support from its operational environment (public or government) which legitimises a company with its environment. Hillman, Shropshire and Cannella (2007), hence posits that independent directors are the most critical resource needed by any company; their presence on the board portrays equality and better career opportunities for prospective employees. This helps an organisation to attract better quality employees, who will drive increases in the company's performance.

\subsection{Legitimacy Theory}

According to Suchman (1995, p. 574), the legitimacy theory states "the actions of an entity are desirable, proper, or appropriate within some socially constructed system of norms, values, beliefs, and definitions". The theory assumes existence some beliefs which gives rise to a social contract between an organisation and the society. This gives approval to an organization to carry out business, and in turn an organisation is expected to provide accountability to the society (Deegan 2013). The legitimacy theory thus emphasises the need for an organisation to comply with the rights and expectations of its host community, failure of which would result in sanctions against the company in the form of restricted access to the market and other key resource (Deegan 2013).

In the East Africa, most companies' operations are controlled by governments via the fiscal policy (tax systems) and the general public who provide market and input resources of materials and labour. Other listed company's stakeholders (with interest and influence) include financial institutions and recently the security 
markets who provide investment capital and the media that influences public opinion about the company's products and services (Mendelow 1991; Tilling 2004). Therefore, listed companies have a legitimate responsibility to meet the expectations of the society (Ashforth \& Gibbs 1990). The legitimate theory has a big influence on corporate governance in the EAC; listed companies often appoint outside (independent) directors from public, government, advocacy and special interest groups, and financial institutions to legitimise their operations.

\subsection{Transactional cost Theory}

This theory was developed from the agency theory (Coase 1937). According to Williamson (1985) and Pound (1993), like in agency theory firms will incur high transaction costs due to the principal - agent conflicts. Ordinarily, principals (shareholders) contracts an agent (manager) to run the company and maximise their wealth. But company performance is often influenced by the manager's behaviour. Due to lack altruism, a manager will often focus on personal pay, privileges and prestige at the expense of shareholder's wealth (Jensen, Michael C \& Meckling 1976). The Transaction cost theory thus focuses on the agent's responsibility in managing (minimising) transaction costs such information gathering, negotiation, re-negotiation and enforcement (Williamson 1985).

Williamson (1988), thus posits that a company's transaction costs are influenced by bounded rationality (the notion of homo economics) and opportunism. Because of management bounded rationality and opportunism, managers tend to make opportunistic decisions on some transaction costs for personal gains or due to limited information or time (Simon, 1982). The transaction cost theory hence calls for stringent measures in managing company transactions to reduce operational costs. The presence of independent directors thus increases company monitoring and supervision while mitigating the risk of excessive transaction costs by the management. Hence the presence of outside directors reduces transaction and agency costs (Benkler 2002; Coase 1937; Jensen, Michael C \& Meckling 1976).

\subsection{Regional Economic Integration and the EAC}

Regional economic integration refers to a joint trade policy by countries aimed at reducing or eliminating trade barriers amongst the member states (Salvatore 2004). It is achievable by linking the member country's economic, social and political infrastructures to enhance each other's economic growth and development (Kehoe 2006). According to Schiff and Winters (2003), there has been a growing trend towards regionalism, which makes economic integration a vital element among the global economies. The idea of regional economic integration was first emerged after World War II (Schiff \& Winters 2003), it then expanded and was embraced by most developed countries globally. One of the best examples of such economic integration was the European Union (EU), which was formed by Luxembourg, Netherlands, United Kingdom, Italy, France and Germany in 1951. It later became the European Economic Community (EEC) in 1957 and the European Free Trade Association (EFTA) in 1960 (Radebaugh, Sullivan \& Daniels 2015). The success of the EEC has encouraged the spread of integration to other regions of Latin America, Asia and Africa (Schiff \& Winters 2003).

According to Mwasha, (2011), economic integration in Africa started in 1910s with the creation of the Southern African Customs Union with membership from South Africa, Botswana, Lesotho, Swaziland and, Namibia. Today Africa has many economic integrations such as; East African Community (EAC), Common Market for Eastern and Southern Africa (COMESA), Economic Community of West African States (ECOWAS), Southern African Development Community (SADC), Economic Community of Central African States (ECCAS) and the Arab Maghreb Union (AMU) among others. Despite the increase in numbers, most economic integration in Africa have not been very effective in delivering the expected economic growth and development (Mwasha 2011). Some of the reasons behind their poor performance include lack of commitment by member countries, political and economic instabilities, external debt problems, currency fluctuations, and narrow tax bases (Matthews 2003).

The EAC economic block is made up of six partner states, namely: Kenya, Uganda, Tanzania, Rwanda, Burundi and South Sudan. It has aggregate population of about 145.5 million, a total land mass of 1.82 million square kilometres and an aggregate Gross Domestic Product (GDP) of US\$ 147.5 billion (EAC 2016). The EAC was first formed in 1917 between Uganda and Kenya and was later joined by Tanzania in 1927, before being dissolved in 1977 (EAC 2016). After its dissolution, the member countries came to a mediation agreement regarding the distribution of the community's assets and liabilities, which was concluded with the signing of the 1984 treaty amongst the then three EAC member states (Kasaija 2004). In the early 1990s, the East Africa region experienced changes in leadership which resulted in significant social, economic and political transformations and the need to revive the EAC as a regional economic integration and promote the development of security markets (EAC 2016; Kasaija 2004).

In the mid-1990s, Uganda, Kenya and Tanzania formed Capital Market Authorities to regulate the activities of the East African Community Security Markets and in 1997, a joint regulatory body known as the East African Securities Regulatory Authorities (EASRA) was formed and mandated with regulating the EAC Security Markets' activities, fast-tracking the EAC Security Markets' integration, harmonising the legal frameworks and market 
infrastructure as well as developing policy guidelines for the capital markets' growth incentives within the EAC (Yabara 2012). Meanwhile, in 2005, the EAC's economic integration had changed from a free trade zone to the East African Community Customs Union, which later became the East African Common Market (EAC- Common Market) in 2010. This transformation led to the advent of corporate governance in the early 2000s among all the EAC countries. Kenya was the first country to introduce a code of corporate governance in 2002 followed by Uganda and Tanzania in 2003 (CMA, K 2002; CMA, U 2003). Rwanda introduced their code of corporate governance in 2010 (RSE 2015)

\subsection{METHODOLOGY}

The main aim for this study was to examine the influence of board independence on the financial performance of listed companies within the EAC. To achieve this objective, we adopted the positivist paradigm under deductive approach, using quantitative techniques to identify the causes and effects of social phenomena (Collis \& Hussey 2013). We adopted the quantitative approach as often used in corporate governance and company performance studies (Alagha 2016; Heenetigala 2011; Waduge 2011). We also adopted a deductive approach, in which hypotheses were developed from the review of existing literature, and data was collected and used to confirm or negate the proposed hypotheses. We based our hypothesis testing on secondary data from published statistics and annual reports. The use of a deductive approach and hypothesis testing method is a consistent with a quantitative research approach (Gill and Johnson, 2010) and was adopted in this study due to its advantages over the qualitative approach. For instance, the use of numerical measurement in the quantitative approach makes it easier for research analysis and presentation of results for explanatory purposes. Additionally, the quantitative approach has less bias error than the qualitative approach (Collis \& Hussey 2013). According to Veal (2005), a qualitative approach does not often provide researchers with the same level of rigour as a quantitative approach.

We obtained our quantitative data from secondary sources, which is the most commonly used method for obtaining data in most business finance, accounting and company performance research studies (Adams, R, Hermalin \& Weisbach 2008; Alagha 2016; Haniffa, R. \& Hudaib 2006; Heenetigala 2011; Kiel \& Nicholson 2003; Klein 1998; Laing \& Weir 1999; Tshipa 2015; Waduge 2011). Our choice of secondary data was therefore based on its suitability in addressing the aforementioned aims of this study.

\subsection{Dependent variables}

We adopted Return on Assets (RoA), Return on Equity (RoE), Tobin Q ratio and Price Earnings Ratio (PeR) as our independent variables as commonly used performance measurement in business, finance, accounting and Corporate governance research (Hermalin \& Weisbach 2008; Alagha 2016; Heenetigala 2011; Kiel \& Nicholson 2003; Klein 1998; Laing \& Weir 1999; Tshipa 2015; Waduge 2011)

3.1.1 Return on Assets (RoA)

The RoA ratio is a measure of company efficiency in generating income from its total assets (Lesakova, 2007). It one of the commonly used accounting measure of performance when evaluating companies' economic health and the proficiency of investment portfolios (Basarab, 2010; Lesakova, 2007). According to Ingram and Albright (2006), the RoA ratio provides a links between company's annual operations and investment activities. The RoA ratio hence measures the efficiency management in using company assets (Lesakova, 2007).

The RoA is calculated as:

Annual Profits after Interest and Tax

$\operatorname{RoA}(\%)=$

Total assets at the year-end

A higher RoA ratio is an indication of management efficiency in utilising company assets to generate a higher value for the investors (Basarab, 2010; Lesakova, 2007).

\subsubsection{Return on Equity (RoE)}

The RoE evaluates company performance based on investment returns. It focuses largely on the management's ability to make an investment return for equity holders in form of financial surplus after deducting all expenses. RoE was calculated in this study as:

Annual Profits after Interest and Tax

$\operatorname{RoE}(\%)=$

Total equity at the Year-end

A higher RoE ratio is an indicator of management's ability to generate extra income to the owners/shareholders 3.1.3 Tobin's $Q$ ratio (TbQ)

Unlike RoA and RoE, the TbQ ratio uses market values when evaluating company performance. It's computed as the ratio of company market value to the asset's book value (Chorafas, 2004).. A lower TbQ ratio is an indicator of poor market confidence in the company shares, which could be attributed to poor governance that reduces company profits (Weir, Laing, \& McKnight, 2002). According to Gross, (2007), TbQ ratio is a hybrid measure of performance, that is based on both accounting and market-based data. TbQ was calculated as: 
Year-end market capitalisation

$\mathrm{TbQ}=$

Total assets at the Year-end

According to Leng (2004), the TbQ ratio measures the company's growth prospects using the company's asset base. A TbQ value of one indicates that the company's market value is equal to the total book value of its assets. If the ratio is greater than one, the company's market value is greater than its asset's book value, and hence management is deemed to have created more value for owners (Chorafas, 2004). On the other hand, a TbQ less than one indicates that the company's market value is lower than the total book value of its assets, which may suggest that the company's share price undervalued (Chorafas, 2004).

3.1.4 Price earnings Ratio (PeR)

The PeR is used to estimate company's market value using the earnings per share (EPS) at the year-end (Bernstein $\&$ Wild, 1993). The value of the company's PeR depends on its governance policies, the past performance future performance potential, and industry risks (Bernstein \& Wild, 1993). If a company posts good past performance results (profitability), high future growth potential (positive net present value projects), it would have a higher PeR than a similar company with poor past performance and low growth potential (Bernstein \& Wild, 1993). Equally, a company with good governance policies will attract affirmative market perceptions which makes it appear less risky than its peers within a same industry. Likewise, high and stable dividend pay-outs will influence a company's PeR because of its market-signalling effect. Consistent dividend pay-outs are a good signal to the market that a company is both financially strong and committed to rewarding its owners (Lease, John, Kalay, Loewenstein, \& Sarig, 1999). This study calculated PeR using the following formula:

Company's year-end share price

$\mathrm{PeR}=$

Earnings per share (EPS)

$\mathrm{PeR}$ is influenced by the company risk, particularly the finance risk or the risk of having debt capital within its capital structure. The presence of debt capital affects the company's bottom line and EPS, hence reducing earnings growth. This also increases the financial risks such as bankruptcy, tax exhaustion, leverage associated with higher PeR ratio (Bernstein \& Wild, 1993).

\subsection{Hypothesis Development}

Our hypotheses were uncured of the assumption that higher proportion of external / independent directors improve the company financial performance (Daily \& Dalton 1992; Schellenger, Wood \& Tashakori 1989). It's a common practice in the EAC for companies to have not less than one-third of the board composed external independent directors (CMA, K 2002; CMA, U 2003; USE 2014). This is in compliance with the codes of corporate governance and good practice in EAC which recommends that any listed company should have at least one-third of directors as non-executive directors. According to Abdullah, (2004), there is a positive and significant correlation between board independence and company financial performance measured by returns on assets, profit margin and earnings per share. Similarly, Fauzi and Locke (2012) studied listed companies in New Zealand from the period 2007-2011 and discovered a significant association between the number of non-executive directors and company performance.

In many developed and emerging economies, board independence is considered as paramount contributor to effective company monitoring and performance (Siddiqui 2015), hence the company laws and regulations mandates all companies to have independent boards for company monitoring and control. The United States of America (USA), for instance introduced the Sarbanes-Oxley Act in 2002 to enforce the need for companies to have a majority of independent directors on their board (Li, X 2014). The choice of the board independence this study was therefore based on the assumption that board independence enhances a board's monitoring capacity, hence it was deemed useful to analyse the extent to which it may or may not influence the EAC-listed companies' financial performance before and after operationalisation of the EAC common market in 2010. The researcher thus hypothesised that:

i. $\quad$ There is a significant relationship between board independence and company financial performance $\left(H_{1}\right)$.

ii. There has been a significant change in board independence after the operationalisation of the EACCommon Market $\left(\mathrm{H}_{2}\right)$.

\subsection{Data collection and sample selection}

We adopted secondary data source mainly because the data required for this study was readily available in company annual reports and databases. The use of secondary data is consistent with other accounting, finance and corporate governance research studies, in which researchers clearly stated that they used secondary data to save time and money for data collection (Beasley, MS 1996; Heenetigala 2011; Ngwenya \& Khumalo 2012; Okiro 2014; Waduge 2011). The type of secondary data used in this study includes journal articles, e-books, press releases and websites. The researcher also obtained financial data from well-established databases, namely Orbis 
Bureau Van Dijk, DataStream, Eikon and Mint Global Bureau Van Dijk. Additional data sources, such as published companies' annual reports and company websites was used in the current study. Microsoft Excel and Statistical Package for the Social Science (SPSS) version 23 was used for data handling and analysis. Excel was used to manage and format data before exporting it into SPSS for statistical annalysis. SPSS was used to carry out the preliminary diagnostic tests, descriptive statistics, correlation, and regression analyses.

We adopted non-probability sampling to select the forty-two listed companies used in ours study. We used listed companies instead of private companies because their information is publicly available (Okiro 2014). We initially intended to use as a population all the listed companies on the EAC Security Markets in 2008/2009 and 2013/2014. A total of 108 companies were listed on the EAC Security Markets as at 31st June 2016. Unfortunately, not all the listed companies qualified to be included in the sample because they were either not listed on the EAC stock market for the full financial years 2008/2009 and 2013/2014, or their annual reports were not available from the DataStream, Eikon and Mint Global Bureau Van Dijk databases.

\subsection{Diagnostics statistical tests}

We adopted a number of diagnostic statistics to ascertain the validity of the regression models used to test the relationship between board independence and company financial performance. We tested normality of the error distribution, homoscedasticity and coefficient of variation tests.

\subsubsection{Normality of the error distribution}

We tested the normality of error distribution using the Shapiro-Wilk test, which is considered as the best measure for identifying any departures from normality distribution due to skewness or kurtosis (Baty et al. 2015). Under the Shapiro-Wilk test, the null hypothesis states that there is no difference between the observed distribution of survey scores and a normally distributed sample error. Hence, if the critical alpha is larger than the obtained pvalue, the null-hypothesis is rejected (Shapiro \& Wilk 1965). The results of the normality test are discussed in section 4 below.

\subsubsection{Heteroscedasticity test}

We tested homoscedasticity using the Koenke tests in the SPSS macro developed by Garcia-Granero (2002). According to Watson and Teelucksingh (2002), Koenker test results are easy to understand and the test can be carried out with small data sample, which makes it suitable for this study's small data sample. The null hypothesis of the heteroscedasticity test implies that there is no conditional heteroscedasticity and thus the individual-specific or time-specific variance error components are equal to zero (Park 2011). The homoscedasticity assumptions of regression were met, and consequently the current study adopted the regression analysis to test the study's hypotheses.

\subsubsection{Coefficient of variation}

The coefficient of variation is calculated as the ratio of the standard error of the estimate to the mean of the dependent variable (Cook \& Krishnan 2015) According to Aiken, West and Pitts (2003), there is no acceptable threshold for a coefficient of variation since it vary across different disciplines but the lower the coefficient of variation, the smaller the residuals relative to the predicted value. The lower coefficient suggests a relatively good model fit compared to a higher coefficient of variation. Nonetheless, there is a drawback in using the coefficient of variation to assess model fit when a variable contains a positive and negative coefficient of variation values and the mean is close to zero, which gives a misleading result (Cook \& Krishnan 2015). The results of the coefficient of variation are discussed below

\subsection{Correlation analysis}

Our diagnostic tests revealed no approximate normal distribution. Hence, this study used Spearman's rank correlation analysis to examine the relationship between board independence company performance indicators. Spearman's rank correlation has been used in previous research on corporate governance and company performance studies (Abdullah, SN 2004; Alagha 2016; Heenetigala 2011).

\subsection{Ordinary least squares (OLS) regression}

We adopted OLS regression which is considered a straightforward method of statistical analysis (Zikmund et al. 2012). We adopted our model using the following equation:

$$
\mathrm{Yi}=\beta \mathrm{o}+\beta_{1} \mathrm{X}+\mathcal{\varepsilon}
$$

Where: $\mathrm{Yi}=$ the dependent variable

$$
\begin{aligned}
& X=\text { the independent variable } \\
& \beta_{0}=\text { intercept } \\
& \beta_{1}=\text { slope and } \\
& \mathcal{E}=\text { error term. }
\end{aligned}
$$

From the above equation, we derive equation $2-6$ used in this study: 
Where: $Y_{t}$ represents dependent variable $\left(\mathrm{PeR}, \mathrm{TbQ}, \mathrm{RoE}\right.$ or RoA) at time`ct, ' $\beta_{0}=$ intercept, $\beta_{\mathrm{i}}=\mathrm{slope}, \mathrm{Bi}=\mathrm{Board}$ independence, and $\boldsymbol{\varepsilon}_{t}$ represents the margin of error due to other factors outside the model that may influence $\mathrm{Y}_{t}$. We thus derived the following four model equations used to test our hypotheses.

$\begin{array}{rllll}\text { i. } & \operatorname{RoA}_{\mathrm{t}} & = & \beta_{\mathrm{o}}+\beta_{1} \mathrm{BI}+\varepsilon \mathrm{t} & 3 \\ \text { ii. } & \operatorname{RoE}_{\mathrm{t}} & = & \beta_{\mathrm{o}}+\beta_{1} \mathrm{BI}+\varepsilon \mathrm{t} & 4 \\ \text { iii. } & \mathrm{TbQ}_{\mathrm{t}} & = & \beta_{\mathrm{o}}+\beta_{1} \mathrm{BI}+\varepsilon \mathrm{t} & 5 \\ \text { iv. } & \operatorname{PeR}_{\mathrm{t}} & = & \beta_{\mathrm{o}}+\beta_{1} \mathrm{BI}+\varepsilon \mathrm{t} & 6\end{array}$

\subsection{RESULTS}

Below the findings of our study represented by the diagnostic test, descriptive statistics, correlation and regression tests.

\subsection{Study Results}

Table 4.1 presents the test results of the normality, heteroscedasticity, and Coefficient of variation used in this study

Table 4:1. Linear regression's diagnostic test results

\section{Source: Own source}

\begin{tabular}{|c|c|c|c|c|c|c|}
\hline \multirow[t]{3}{*}{$\begin{array}{l}\text { Threshold } \\
\text { assumption: }\end{array}$} & 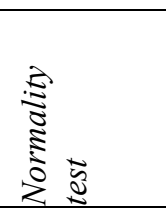 & 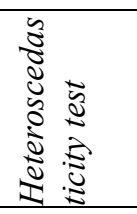 & 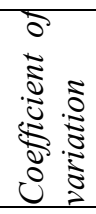 & 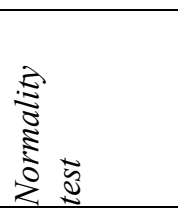 & 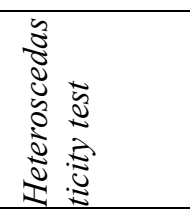 & 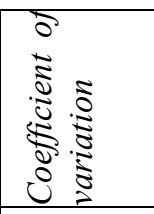 \\
\hline & $\mathrm{p}>0.05$ & $\mathrm{p}>0.05$ & Low & $\mathrm{p}>0.05$ & $\mathrm{p}>0.05$ & Low \\
\hline & Shap.Wilk & Koenker & & Shap.Wilk & Koenker & \\
\hline \multicolumn{4}{|l|}{$2013 / 2014$} & \multicolumn{3}{|r|}{$2008 / 2009$} \\
\hline RoA & 0.076 & 0.064 & 0.193 & 0.124 & 0.056 & 0.245 \\
\hline RoE & 0.930 & 0.064 & 0.117 & 0.780 & 0.056 & 0.092 \\
\hline TbQ & 0.326 & 0.064 & 0.131 & 0.155 & 0.056 & 0.252 \\
\hline PeR & 0.438 & 0.064 & 0.177 & 0.852 & 0.056 & 0.239 \\
\hline
\end{tabular}

4.1.1 Normality of the error distribution

We tested normality distribution of the residual using the Shapiro-Wilk test, which is as a dominant tool in detecting any departure from normality due to kurtosis or skewness (Baty et al. 2015). The Shapiro-Wilk test's statistical significance ranges from zero to one. Any value higher than 0.05 is an indication that the residual is normally distributed (Baty et al. 2015; Razali \& Wah 2011). The p values for the Shapiro-Wilk tests on residual normality in 2008/2009 for PeR, was 0.852 , $\mathrm{TbQ}=0.155$, $\mathrm{RoE}=0.780$ and $\mathrm{RoA}=0.124$, while in $2013 / 2014, \mathrm{PeR}$ was $0.438, \mathrm{TbQ}=0.326, \mathrm{RoE}=0.930$ and $\mathrm{RoA}=0.076$. These values are all above the significance value of 0.05 , which therefore confirms that the residual is normally distributed in this study (Shapiro \& Wilk 1965).

4.1.2 Heteroscedasticity test

We carried out heteroscedasticity test using the Koenker tests in the SPSS macro developed by Garcia-Granero (2002). The null hypothesis in the Koenker test assumes that homoscedasticity is present (or heteroscedasticity is not present). The $p$ values of the Koenker tests of homoscedasticity in 2008/2009 and 2013/2014 was 0.056 and 0.064 respectively meaning that the $2008 / 2009$ and $2013 / 2014$ are homoscedastic $(p>0.05)$

\subsubsection{Coefficient of variation}

The results of the coefficient of variation in 2013/2014 are as follows: $\mathrm{RoA}=0.193$, $\mathrm{RoE}=0.117, \mathrm{TbQ}=0.131$ and PeR was 0.177. Similarly, in 2008/2009, the coefficient of variation for RoA $=0.245$, RoE $=0.092, T b Q=$ 0.252 and $\mathrm{PeR}=0.239$. According to Cook and Krishnan (2015), the lower the coefficient of variation, the smaller the residuals relative to the predicted value, the above results thus suggests a relatively good model-fit.

\subsection{Descriptive statistics}

We adopted the mean, median, maximum, minimum and standard deviation to identify the statistical characteristics of the study's independent and dependent variables as indicated in table 4.2, below 
Table 4:2. Descriptive Statistics

\begin{tabular}{|c|c|c|c|c|c|c|c|}
\hline & No & Mean & Median & Std. Dev. & Minimum & Maximum & Years \\
\hline RoA (\%) & 42 & 40.581 & 40.109 & 4.263 & 32.758 & 50.570 & \multirow{5}{*}{ 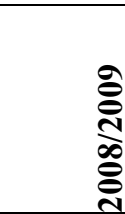 } \\
\hline RoE (\%) & 42 & 40.793 & 41.740 & 10.007 & 19.343 & 62.396 & \\
\hline TbQ & 42 & 0.425 & 0.390 & 1.913 & 0.165 & 2.038 & \\
\hline PeR & 42 & 9.743 & 9.812 & 1.884 & 2.719 & 37.341 & \\
\hline BI (\%) & 42 & 76.869 & 81.818 & 14.549 & 33.333 & 91.667 & \\
\hline RoA (\%) & 42 & 40.009 & 39.083 & 9.085 & 19.105 & 63.863 & \multirow{5}{*}{ 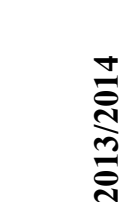 } \\
\hline RoE (\%) & 42 & 39.229 & 41.318 & 11.497 & 7.090 & 64.121 & \\
\hline TbQ & 42 & 0.466 & 0.441 & 3.107 & 0.056 & 6.936 & \\
\hline PeR & 42 & 11.056 & 11.364 & 2.058 & 1.766 & 52.375 & \\
\hline BI (\%) & 42 & 76.106 & 80.909 & 15.551 & 33.333 & 93.333 & \\
\hline
\end{tabular}

Where: $\mathrm{BI}=$ Board independence, $\mathrm{RoA}=$ Return on Asset, RoE $=$ Return on Equity, $\mathrm{TbQ}=$ Tobins $\mathrm{Q}$ ratio and $\mathrm{PeR}=$ Price Earnings ratio

\section{Source: Own source}

\subsubsection{Return on assets (RoA)}

Analysis of 2008/2009 descriptive statistics on RoA, as shown in Table 4.2, indicates a mean of 40.58\%, median of $40.11 \%$, standard deviation of 4.26 , minimum of $32.76 \%$ and maximum of $50.57 \%$. For $2013 / 2014$, the mean RoA was $40.01 \%$, median $39.08 \%$, standard deviation 9.09 , minimum $19.11 \%$ and maximum $63.86 \%$. There is a positive mean value in both periods, which indicates that the EAC-listed companies in this study on average generated a similar positive return of about $40 \%$ on assets for their shareholders before $(2008 / 2009)$ and after $(2013 / 2014)$ the establishment of the EAC-Common Market.

4.2.2 Return on equity (RoE)

Analysis of 2008/2009 descriptive statistics on RoE in Table 4.2 indicated a mean of $40.79 \%$, median of $41.74 \%$, standard deviation of 10.01 , minimum of $19.34 \%$, and the maximum of $63.40 \%$. The RoE mean and median values for both 2008/2009 and 2013/2014 indicate that the EAC-listed companies in this study generated a similar average positive return of about $40 \%$ for their shareholders before (2008/2009) and after (2013/2014) the establishment of the EAC-Common Market.

\subsubsection{Tobin's q ratio (TbQ)}

The TbQ descriptive statistics results in Table 4.2 show that for 2008/2009, TbQ had a mean of 0.4251 , median of 0.390 , standard deviation 1.913 , minimum of 0.165 , and maximum of 2.038 . For $2013 / 2014$, the TbQ descriptive statistic results included a mean of 0.466 , median of 0.441 , standard deviation of 3.107 minimum of 0.056 , and maximum of 6.936. The descriptive statistics for TbQ indicates that EAC listed companies experiences higher volatility in 2013/2014, after the establishment of the EAC-Common Market. The degree of volatility (Standard deviation) in TbQ increased by $62 \%$ in $2013 / 2014$ as compared to $2008 / 2009$.

4.2.4 Price earnings ratio (PeR)

The descriptive statistics results for 2008/2009 indicate an PeR mean of 9.743, median of 9.812, standard deviation of 1.884 , minimum of 2.719 , and maximum of 37.341 . On the other hand, in 2013/2014, the descriptive statistic results for PeR showed a mean of 11.056, median of 11.364, standard deviation of 2.058, minimum of 1.766 , and maximum of 52.375. The PeR's positive means and medians for both 2008/2009 and 2013/2014 are an indication that the EAC-listed companies continued to create value for their shareholders after the operationalisation of the EAC-Common Market in 2010.

4.2.5 Board independence

During 2008/2009, board independence had a mean value of $76.87 \%$, median of $81.82 \%$, standard deviation of 14.55 , and minimum of $33.33 \%$ and maximum of $91.67 \%$. Four years after operationalisation of the EACCommon Market, the mean board independence was $76.11 \%$, the median was $80.91 \%$, the standard deviation was 15.55 , the minimum board independence remained at $33.33 \%$ and the maximum was $93.33 \%$. The above results indicate that the majority of companies in the EAC had more external than internal directors on their boards. The reason for the minimum board independence of $33.33 \%$ in the study data is that the corporate governance codes in all the EAC countries recommend that at least one-third of directors should be non-executive directors (CMA, K 2002; CMA, U 2003; USE 2014). Hence, the 33.33\% minimum percentage for board independence in 2008/2009 and 2013/2014 (Table 4.2) demonstrate that all companies maintained the degree of board independence recommended by the EAC's code of governance and good practice. 


\subsection{Spearman's correlation results}

Table 4:3 Spearmen's rank correlation analysis

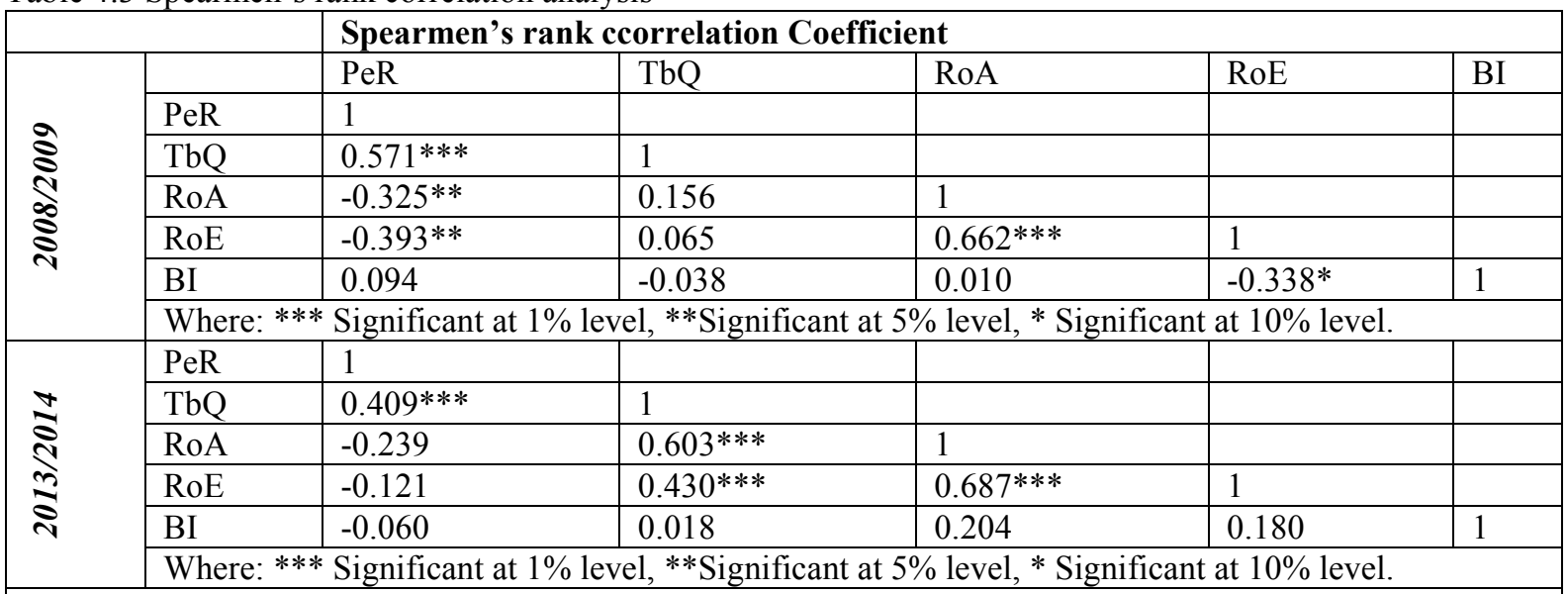

$\mathrm{BI}=$ Board independence, $\mathrm{RoA}=$ Return on Asset, $\mathrm{RoE}=$ Return on Equity, $\mathrm{TbQ}=$ Tobin's $\mathrm{Q}$ ratio and $\mathrm{PeR}=$ Price Earnings ratio

\section{Source: Own source}

Table 4.3 indicate Spearman's rank correlation for 2008/2009 had the following pair of variables with significant correlation at $1 \%$ significance: RoA and RoE with correlation coefficient of 0.662 , PeR and TbQ with correlation coefficient of 0.571 . Those with a significant e pairs of variables that displayed significant correlation at 5\% significance were: PeR and RoA with correlation coefficient of $-0.325, \mathrm{PeR}$ and RoE with correlation coefficient of -0.393 , RoE and BI with correlation coefficient of -0.338 . While in $2013 / 2014$, the following pair of variables showed significant correlation at $1 \%$ significance: PeR and TbQ with correlation coefficient of 0.409 , TbQ and RoA with correlation coefficient of 0.603 , TbQ and RoE with correlation coefficient of -0.43 , RoA and RoE with correlation coefficient of 0.687 , The above correlation figures indicate lack or lower correlations between the dependent and independent variables which is common with many business, accounting and finance research using non independent variables with no linear relation.

\subsection{Ordinary least squares (OLS) regression results}

We interpreted OLS regression results considering the coefficients, the R-squared values and the $\mathrm{P}$ values. According to Bowerman et al. (2003) the variable coefficient shows the size of effect that one variable has over the dependent variable. Positive coefficients indicates how much the dependent variable is expected to increase when the independent variable increases by one unit, holding other variables constant and the reverse is true for the negative coefficient (Tabachnick \& Fidell 2006; Tabachnick, Fidell \& Osterlind 2001). The R-squared is the fraction of the variation in the dependent variable that is predictable by an independent variable. The $\mathrm{P}$ value for each independent variable tests the null hypothesis that the coefficient is equal to zero. If the null hypothesis is not rejected, the respective independent variable has no effect on the dependent variable (Field 2009).

4.4.1 Influence of Board Independence on RoA

Table 4.4, below, presents a summary of the regression results on the relationship between Board Independence and RoA in 2008/2009 and 2013/2014.

Table 4.4: Regression analysis of Board Independence and RoA

\begin{tabular}{|c|c|c|c|c|c|c|}
\hline \multirow[t]{2}{*}{ Dependent variable: RoA } & \multicolumn{3}{|c|}{$2008 / 2009$} & \multicolumn{3}{|c|}{$2013 / 2014$} \\
\hline & \multicolumn{3}{|c|}{$\begin{array}{l}\text { Model fit: } \mathrm{R}^{2}=0.4960 \\
\quad \mathrm{P}=0.0023 \\
\mathrm{~F}=1.6809\end{array}$} & \multicolumn{3}{|c|}{$\begin{array}{l}\text { Model fit: } \mathrm{R}^{2}=0.5426 \\
\mathrm{P}=0.0003 \\
\mathrm{~F}=5.8543\end{array}$} \\
\hline Independent Variables & Coeff & $\mathrm{T}$ & $\mathrm{P}$ & Coeff & $\mathrm{T}$ & $\mathrm{P}$ \\
\hline Constant & 60.843 & 6.091 & 0.000 & 52.834 & 3.713 & 0.001 \\
\hline Board independence & 0.855 & 1.771 & $0.087 *$ & -0.409 & -0.613 & 0.544 \\
\hline
\end{tabular}

\section{Source: Own source}

The 2008/2009 results show an adjusted R-squared value of 0.496 , which indicates that about $50 \%$ of the total variability in RoA is explained by board independence. Hence board independence has a statistically significant positive influence on RoA $(\mathrm{p}=0.09<0.10)$; hence an increase in board Independence by one percent would result in an increase in the RoA by $86 \%$, holding all other variables constant. On the other hand, the $2013 / 2014$ results show an adjusted R-squared value of 0.542 which can be interpreted; about $54 \%$ of the total variability in RoA is explained board independence but board independence does not statistically and significantly 
influence on RoE RoA.

4.4.2 The influence of Board Independence on RoE

The RoE represents the net amount of profits created by the company using shareholders' funds (Khatab et al., 2011). Table 4. 5, below, presents a summary of the regression results on the relationship between board independence and RoE.

Table 4.5. Regression analysis of board independence and RoE

\begin{tabular}{|c|c|c|c|c|c|c|}
\hline \multirow[t]{2}{*}{ Dependent variable: RoE } & \multicolumn{3}{|c|}{$2008 / 2009$} & \multicolumn{3}{|c|}{$2013 / 2014$} \\
\hline & \multicolumn{3}{|c|}{$\begin{array}{l}\text { Model fit: } \mathrm{R}^{2}=0.4721 \\
\quad \mathrm{P}=0.0997 \\
\mathrm{~F}=1.9820\end{array}$} & \multicolumn{3}{|c|}{$\begin{array}{l}\text { Model fit: } \mathrm{R}^{2}=0.5168 \\
\qquad \mathrm{P}=0.0001 \\
\mathrm{~F}=6.3576\end{array}$} \\
\hline Independent Variables & Coeff & $\mathrm{T}$ & $\mathrm{P}$ & Coeff & $\mathrm{T}$ & $\mathrm{P}$ \\
\hline Constant & 62.223 & 2.924 & 0.007 & 26.876 & 1.411 & 0.167 \\
\hline Board independence & -0.245 & -2.069 & $0.047 * *$ & 0.105 & 0.712 & 0.481 \\
\hline
\end{tabular}

\section{Source: Own Source}

As shown in Table 4.5 above, in 2008/2009, regression results show an adjusted R-squared value of 0.472 , which suggests that about $47 \%$ of the total variability in RoE is explained by board independence. Board independence had a statistically significant negative influence on $\operatorname{RoE}(\mathrm{p}=0.05<0.10)$, hence, an increase in board independence by one percent would result in a decrease in the RoE of $25 \%$ holding other variables constant. On the other hand, the results for 2013/2014 presented an adjusted R-squared value of 0.52 , which shows a better model fit than 2008/2009. The adjusted R-squared results indicates that during 2013/2014, about 52\% of the total variability in RoE could be attributed to board independence but board independence does not statistically and significantly influence on RoE.

4.4.3 The influence of Board Independence on $T b Q$

Table 4.5, below, presents a summary of the regression results on the relationship between TbQ and Board Independence in 2008/2009 and 2013/2014.

Table 4.5: Regression analysis of Board Independence on the TbQ and TbQ

\begin{tabular}{|c|c|c|c|c|c|c|}
\hline \multirow[t]{2}{*}{ Dependent variable: TbQ } & \multicolumn{3}{|c|}{$2008 / 2009$} & \multicolumn{3}{|c|}{$2013 / 2014$} \\
\hline & \multicolumn{3}{|c|}{$\begin{array}{l}\text { Model fit: } \mathrm{R}^{2}=0.4088 \\
\mathrm{P}=0.2719 \\
\mathrm{~F}=1.3368\end{array}$} & \multicolumn{3}{|c|}{$\begin{array}{l}\text { Model fit; } \mathrm{R}^{2}=0.7368 \\
\quad \mathrm{P}=0.0000 \\
\mathrm{~F}=8.6757\end{array}$} \\
\hline Independent Variables & Coeff & $\mathrm{T}$ & $P$ & Coeff & $T$ & $\mathrm{P}$ \\
\hline Constant & 2.129 & 1.347 & 0.188 & 5.751 & 4.840 & 0.000 \\
\hline Board independence & -0.332 & -2.294 & 0.019 & -0.642 & -6.749 & $0.000^{* * *}$ \\
\hline
\end{tabular}

\section{Source: Own Source}

According to the OLS regression results in Table 4.5, the adjusted R-squared value in 2008/2009 was 0.41 , which suggests that about $41 \%$ of the total variability in TbQ can be explained by board independence but board independence does not statistically and significantly influence on TbQ. The 2013/2014 results, shows an adjusted R-squared value of 0.74 , which demonstrates that about $74 \%$ of the total variability in TbQ can be explained by board independence. Board independence had a statistically significant negative influence on $\mathrm{TbQ}(\mathrm{p}=0.00<0.01)$, hence, an increase in board independence by one percent would result in a decrease in the TbQ of $64 \%$ holding other variables constant.

4.4.4 The influence of Board Independence on PeR

Table 4.6, below, presents a summary of the regression results on the relationship between PeR and Board Independence in 2008/2009 and 2013/2014.

Table 4.6: Regression analysis of Board Independence on the TbQ and TbQ

\begin{tabular}{|c|c|c|c|c|c|c|}
\hline \multirow[t]{2}{*}{ Dependent variable: PeR } & \multirow{2}{*}{\multicolumn{3}{|c|}{$\begin{array}{l}\text { 2008/2009 } \\
\text { Model fit: } \mathrm{R}^{2}=0.1834 \\
\mathrm{P}=0.2402 \\
\mathrm{~F}=1.4186\end{array}$}} & \multirow{2}{*}{\multicolumn{3}{|c|}{$\begin{array}{l}\text { 2013/2014 } \\
\text { Model fit; } \mathrm{R}^{2}=0.4099 \\
\mathrm{P}=0.0038 \\
\mathrm{~F}=3.9907\end{array}$}} \\
\hline & & & & & & \\
\hline Independent Variables & Coeff & $\mathbf{T}$ & $\mathbf{P}$ & Coeff & $\mathbf{T}$ & $\mathbf{P}$ \\
\hline Constant & 3.921 & 3.312 & 0.002 & 52.824 & 3.713 & 0.000 \\
\hline Board independence & 0.004 & 0.473 & 0.640 & 0.032 & 0.309 & 0.236 \\
\hline
\end{tabular}

\section{Source: Own Source}

The 2008/2009 results (Table 4.6) show an adjusted R-squared value of 0.18 , which means that during $2008 / 2009$, only $18 \%$ of the total variability in PeR is explained by board independence. On the other hand, in 
$2013 / 2014$ results, the adjusted R-squared value was 0.41 , which indicates that about $41 \%$ of the total variability in PeR in 2013/2014 can be explained by board independence and board independence does not statistically and significantly influence on PeR for both 2008/2009 and2013/2014.

4.4.5 Summary of the hypothesis test results.

Presented in table 4.7 , below is the summary of the hypothesis tests results for the two hypotheses used in this study.

Table 4.7, Summary of the hypothesis tests results and previous studies

\begin{tabular}{|c|c|c|c|c|}
\hline \multirow{2}{*}{$\begin{array}{l}\text { Study } \\
\text { hypothesises }\end{array}$} & \multicolumn{2}{|l|}{ Tests results } & \multirow{2}{*}{$\begin{array}{l}\text { Overall } \\
\text { result }\end{array}$} & \multirow{2}{*}{$\begin{array}{l}\text { Results of prior studies on the influence of corporate } \\
\text { governance and firm's financial performance }\end{array}$} \\
\hline & $2008 / 2009$ & $2013 / 2014$ & & \\
\hline \multicolumn{3}{|c|}{$\begin{array}{l}\mathrm{H}_{1} \text { : There is a significant relationship } \\
\text { between board independence and } \\
\text { company financial performance }\end{array}$} & \multirow[t]{5}{*}{ Inconclusive } & \multirow{5}{*}{$\begin{array}{l}\text { Supported } \\
\text { - } \quad \text { New Zealand-listed companies using RoA } \\
\text { (Fauzi \& Locke 2012) } \\
\text { - Malaysian companies using TbQ (Ameer, Ramli } \\
\text { \& Zakaria 2010) } \\
\text { - Africa-listed companies using TbQ and RoA } \\
\text { (Kyereboah-Coleman 2008) } \\
\text { - Malaysian-listed firms using RoA, PE and EPS } \\
\text { share (Abdullah, SN 2004) } \\
\text { Not supported/ inconclusive } \\
\text { - Hong Kong nonfamily firms using TbQ (Leung, } \\
\text { Richardson \& Jaggi 2014). } \\
\text { Listed companies in India using RoA (Garg } \\
\text { 2007) } \\
\text { Africa-listed companies using EPS and DPS } \\
\text { (Kyereboah-Coleman 2007) } \\
\text { USA 142 NYSE-listed companies using TbQ } \\
\text { (Hermalin \& Weisbach 1991) }\end{array}$} \\
\hline BI and $\operatorname{RoA}$ & Supported & $\begin{array}{l}\text { Not } \\
\text { supported }\end{array}$ & & \\
\hline BI and RoE & Supported & $\begin{array}{l}\text { Not } \\
\text { supported }\end{array}$ & & \\
\hline BI and TbQ & $\begin{array}{l}\text { Not } \\
\text { Supported }\end{array}$ & Supported & & \\
\hline BI and PeR & $\begin{array}{l}\text { Not } \\
\text { Supported }\end{array}$ & $\begin{array}{l}\text { Not } \\
\text { Supported }\end{array}$ & & \\
\hline \multicolumn{3}{|c|}{$\begin{array}{l}\mathrm{H}_{2} \text { There has been a significant change } \\
\text { in board independence following the } \\
\text { operationalisation of the EAC- } \\
\text { Common Market in } 2020\end{array}$} & Inconclusive & $\begin{array}{l}\text { - No similar study with similar objective has been } \\
\text { carried out since the operationalisation of the } \\
\text { East African common market }\end{array}$ \\
\hline
\end{tabular}

\section{Source: Own Source}

\subsection{REFERENCES}

Abdullah, H \& Valentine, B 2009, 'Fundamental and ethics theories of corporate governance', Middle Eastern Finance and Economics, vol. 4, no. 4, pp. 88-96.

Abdullah, SN 2004, 'Board composition, CEO duality and performance among Malaysian listed companies', Corporate governance, vol. 4, no. 4, pp. 47-61.

Adams, R, Hermalin, BE \& Weisbach, MS 2008, The role of boards of directors in corporate governance: A conceptual framework and survey, National Bureau of Economic Research.

AdeBIite, E 2012, 'Corporate governance regulation in Nigeria', Corporate Governance: The international journal of business in society, vol. 12, no. 2, pp. 257-76.

Agarwal, Y 2013, Capital structure decisions: Evaluating risk and uncertainty, John Wiley \& Sons.

Agyekum, AAB, Otchere, FA \& Bedi, I 2014, 'Earnings management and corporate governance: the Ghanaian experience', International Journal of Management Practice, vol. 7, no. 4, p. 309

Aik, NC, Hassan, T \& Mohamad, S 2015, 'Do Malaysian Horizontal Mergers and Acquisitions Create Value?', Global Business Review, vol. 16, no. 5 suppl, pp. 15S-27S.

Aiken, LS, West, SG \& Pitts, SC 2003, 'Multiple linear regression', Handbook of psychology.

Ameer, R, Ramli, F \& Zakaria, H 2010, 'A new perspective on board composition and firm performance in an emerging market', Corporate Governance: The international journal of business in society, vol. 10, no. 5, pp. 647-61.

Ansong, A 2013, 'Risk Management as a Conduit of Effective Corporate Governance and Financial Performance of Small and Medium Scale Enterprises', Developing Country Studies, vol. 3, no. 8, pp. 159-63.

Ashforth, BE \& Gibbs, BW 1990, 'The Double-Edge of Organizational Legitimation', Organization science, vol. 1, no. 2, pp. 177-94.

Basarab, D 2010, Predictive evaluation: Ensuring training delivers business and organizational results, BerrettKoehler Publishers.

Baty, F, Ritz, C, Charles, S, Brutsche, M, Flandrois, JP \& Delignette-Muller, ML 2015, 'A Toolbox for Nonlinear 
Regression in R: The Package nlstools', Journal of Statistical Software, vol. 66

Baysinger, BD \& Butler, HN 1985, 'Corporate governance and the board of directors: Performance effects of changes in board composition', Journal of Law, Economics, \& Organization, vol. 1, no. 1, pp. 101-24.

Beasley, MS 1996, 'An empirical analysis of the relation between the board of director composition and financial statement fraud', Accounting review, vol. 71, no. 4, pp. 443-65.

Bernstein, LA \& Wild, JJ 1993, Analysis of financial statements, Business One Irwin.

Bhagat, S \& Bolton, B 2008, 'Corporate governance and firm performance', Journal of Corporate Finance, vol. 14, no. 3 , pp. $257-73$.

Bowerman, BL, O'Connell, RT, Murphree, E, Huchendorf, SC \& Porter, DC 2003, Business statistics in practice, McGraw-Hill/Irwin New York.

Bromiley, P, McShane, M, Nair, A \& Rustambekov, E 2015, 'Enterprise Risk Management: Review, Critique, and Research Directions', Long range planning, vol. 48, no. 4, pp. 265-76.

Cadbury, A 1992, Report of the committee on the financial aspects of corporate governance, December edn, vol. 1 , London, UK.

Chorafas, DN 2004, The Management of Equity Investments, Butterworth-Heinemann.

Claessens, S \& Yurtoglu, BB 2013, 'Corporate governance in emerging markets: A survey', Emerging Markets Review, vol. 15, pp. 1-33.

CMA, K 2002, 'Guidelines on Corporate Governance in public listed Companies in Kenya', Kenya Gazette Notice No. 369, 122, vol. 128.

CMA, U 2003, The capital markets corporate governance guidelines; Uganda, viewed 18 Dec. 2016, $<$ http://www.cmauganda.co.ug/files/downloads/Corporate\%20Governance\%20Guidelines.pdf $>$.

Cook, DJ \& Krishnan, NC 2015, Activity Learning: Discovering, Recognizing, and Predicting Human Behavior from Sensor Data, John Wiley \& Sons.

Daily, CM \& Dalton, DR 1992, 'The Relationship between Governance Structure and Corporate Performance in Entrepreneurial Firms', Journal of Business Venturing, vol. 7, no. 5, pp. 375-86.

De Aguiar, AB, Pinheiro, PN \& Oyadomari, JCT 2014, 'How do different performance measures affect managerial time orientation? Empirical evidence from sales managers in the oil and gas industry', Advances in Accounting, vol. 30, no. 1, pp. 143-53.

Dore, R 1993, 'What makes the Japanese different?', Ethics and Markets: Cooperation and Competition within Capitalist Economies (Blackwell) pp, pp. 66-79.

EAC 2015, East African Community: One people one destiny, viewed 29 July 2015, $<$ http://www.eac.int/index.php?option=com_content\&view=frontpage\&Itemid=1 $>$.

EAC 2016, East African Community: One people one destiny, viewed 15 March 2016, <<http://www.eac.int/ $>$. $>$.

Eikelenboom, B 2005, Organizational capabilities and bottom line performance: The relationship between organizational architecture and strategic performance of business units in Dutch headquartered multinationals, Eburon Uitgeverij BV.

Fauzi, F \& Locke, S 2012, 'Board structure, ownership structure and firm performance: A study of New Zealand listed-firms'.

Feltham, GA \& Xie, J 1994, 'Performance measure congruity and diversity in multi-task principal/agent relations', Accounting review, pp. 429-53.

Forker, JJ 1992, 'Corporate governance and disclosure quality', Accounting and Business research, vol. 22, no. 86, pp. 111-24.

Fosberg, RH 1989, 'Outside Directors and Managerial Monitoring', Akron Business and Economic Review, vol. 20, no. 2, pp. 24-32.

Garg, AK 2007, 'Influence of board size and independence on firm performance: A study of Indian companies', Vikalpa, vol. 32, no. 3, pp. 39-60.

Gitundu, EW, Kisaka, SE, Kiprop, SK \& Kibet, LK 2016, 'The effects of ownership and corporate governance reforms on efficiency of privatized companies in Kenya', International Journal of Economics and Financial Issues, vol. 6, no. 1, pp. 323-31.

Grace, MF, Leverty, JT, Phillips, RD \& Shimpi, P 2015, 'The Value of Investing in Enterprise Risk Management', Journal of Risk and Insurance, vol. 82, no. 2, pp. 289-316.

Gross, K 2007, Equity ownership and performance: An empirical study of German traded companies, Springer Science \& Business Media.

Haniffa, R \& Hudaib, M 2006, 'Corporate governance structure and performance of Malaysian listed companies', Journal of Business Finance \& Accounting, vol. 33, no. 7-8, pp. 1034-62.

Hayes, AF \& Cai, L 2007, 'Using heteroskedasticity-consistent standard error estimators in OLS regression: An introduction and software implementation', Behavior Research Methods, vol. 39, no. 4, pp. 709-22.

Heenetigala, K 2011, 'Corporate governance practices and firm performance of listed companies in Sri Lanka', Victoria University Melbourne. 
Hengartner, L 2006, Explaining Executive Pay: The roles of management power and complexity, Wiesbaden.

Hermalin, BE \& Weisbach, MS 1991, 'The Effects of Board Composition and Direct Incentives on Firm Performance', Financial management, vol. 20, no. 4, pp. 101-12.

Hillman, AJ, Cannella, AA \& Harris, IC 2002, 'Women and racial minorities in the boardroom: How do directors differ?', Journal of management, vol. 28, no. 6, pp. 747-63.

Hirshleifer, J 1958, 'On the theory of optimal investment decision', The Journal of Political Economy, pp. 329-52.

Ingram, RW \& Albright, TL 2006, Financial Accounting: Information for Decisions: Information for Decisions, Cengage Learning.

Jensen, MC 1993, 'The Modern Industrial-Revolution, Exit, and the Failure of Internal Control-Systems', Journal of Finance, vol. 48, no. 3, pp. 831-80.

Jensen, MC \& Meckling, WJ 1976, 'Theory of the firm: Managerial behavior, agency costs, and ownership structure'.

Johnson, JL, Daily, CM \& Ellstrand, AE 1996, 'Boards of directors: A review and research agenda', Journal of management, vol. 22, no. 3, pp. 409-38.

Kasaija, PA 2004, 'Regional integration: A political federation of the East African Countries?', African Journal of International Affairs, vol. 7, no. 1-2.

Katto, J, Wanyama, S \& Musaali, EM 2014, Corporate Governance in Uganda; An introduction to concepts and principles., vol. 1, Fountain Publishers, Kampala.

Kehoe, WJ 2006, Regional and Global Economic Integration: Implications for Global Business.

Kiel, GC \& Nicholson, GJ 2003, 'Board composition and corporate performance: how the Australian experience informs contrasting theories of corporate governance', Corporate Governance-an International Review, vol. 11, no. 3, pp. 189-205.

Kim, K 2015, 'Revisiting the relationship between financial and environmental performance: Does Granger causality matter?', Journal of Applied Business Research, vol. 31, no. 5, pp. 1861-76.

Kyereboah-Coleman, A 2007, 'Corporate governance and shareholder value maximization: An African perspective', African Development Review-Revue Africaine De Developpement, vol. 19, no. 2, pp. 350-67.

_ 2008, 'Corporate governance and firm performance in Africa: A dynamic panel data analysis', Journal for Studies in Economics and Econometrics, vol. 32, no. 2, pp. 1-24.

Laing, D \& Weir, CM 1999, 'Governance structures, size and corporate performance in UK firms', Management Decision, vol. 37, no. 5, pp. 457-64.

Lease, RC, John, K, Kalay, A, Loewenstein, U \& Sarig, OH 1999, 'Dividend Policy: Its Impact on Firm Value', OUP Catalogue.

Lee, L-E, Marshall, R, Rallis, D \& Moscardi, M 2015, 'Women on Boards: Global trends in gender diversity on corporate boards', p. 31, viewed 01 March, <https://www.msci.com/documents/10199/04b6f646-d638-4878$9 \mathrm{c} 61-4 \mathrm{eb} 91748 \mathrm{a} 82 \mathrm{~b}>$.

Leng, ACA 2004, 'The impact of corporate governance practices on firms' financial performance: Evidence from Malaysian companies', ASEAN Economic Bulletin, pp. 308-18.

Lesakova, L 2007, 'Uses and limitations of profitability ratio analysis in managerial practice', in International Conference on Management, Enterprise and Benchmarking, pp. 1-2.

Leung, S, Richardson, G \& Jaggi, B 2014, 'Corporate board and board committee independence, firm performance, and family ownership concentration: An analysis based on Hong Kong firms', Journal of Contemporary Accounting \& Economics, vol. 10, no. 1, pp. 16-31.

Li, SL \& Tallman, S 2011, 'Mnc Strategies, Exogenous Shocks, and Performance Outcomes', Strategic management journal, vol. 32, no. 10, pp. 1119-27.

Li, X 2014, 'The Sarbanes-Oxley act and cross-listed foreign private issuers', Journal of Accounting \& Economics, vol. 58 , no. 1 , pp. 21-40.

Lussier, R 2011, Management fundamentals: Concepts, applications, skill development, Cengage Learning.

Manab, NA, Kassim, I \& Hussin, MR 2010, 'Enterprise-wide risk management (EWRM) practices: Between corporate governance compliance and value', International Review of Business Research Papers, vol. 6, no. 2, pp. 239-52.

Mans-Kemp, N 2014, Corporate governance and the financial performance of selected Johannesburg stock exchange industries, Stellenbosch University, Cape Town.

Margolis, JD \& Walsh, JP 2001, People and profits? The search for a link between a company's social and financial performance, Psychology Press.

Masulis, RW \& Mobbs, S 2011, 'Are all inside directors the same? Evidence from the external directorship market', The journal of Finance, vol. 66, no. 3, pp. 823-72.

Matthews, A 2003, Regional integration and food security in developing countries, vol. 45, Food \& Agriculture Org.

Mattingly, JE 2004, 'Redefining the corporation: Stakeholder management and organizational wealth', Academy 
of management review, vol. 29, no. 3, pp. 520-3.

Meyer, E \& de Wet, JHVH 2013, 'The impact of board structure on the financial performance of listed South African companies', Corporate Board: Role, Duties and Composition, vol. 9, pp. 19-31.

Miller, MH \& Modigliani, F 1958, 'The cost of capital, corporation finance and the theory of investment', The American economic review, pp. 261-97.

1961, 'Dividend policy, growth, and the valuation of shares', the Journal of Business, vol. 34, no. 4, pp. 41133.

Moldasheva, G 2015, 'Corporate governance practices in emerging markets: Evidence from Kazakhstan financial system', Corporate Ownership and Control, vol. 13, no. 1CONT8, pp. 889-906.

Morekwa Nyamongo, E \& Temesgen, K 2013, 'The effect of governance on performance of commercial banks in Kenya: a panel study', Corporate Governance: The international journal of business in society, vol. 13, no. 3, pp. 236-48.

Mulsow, R 2011, 'The Relationship between Project-Portfolio Success and multi-dimensional Business Success'.

Mwasha, ON 2011, '„,The Benefits of Regional Economic Integration for Developing Countries in Africa : A Case of East African Community (EAC)'.

Ngwenya, S \& Khumalo, M 2012, 'CEO compensation and performance of state owned enterprises in South Africa', Corporate Ownership and Control, vol. 10, no. 1 A, pp. 97-109.

OECD 1999, OECD Principles of Corporate Governance, viewed 18 December 2014, $<$ http://www.ecgi.org/codes/code.php?code_id=89>.

2004, OECD Principles of Corporate Governance, viewed 18 December 20142014 , $<$ http://www.ecgi.org/codes/code.php?code_id=87>.

2015, G20/OECD Principles of Corporate Governance viewed 20 October 2015, $<$ http://www.ecgi.org/codes/all_codes.php $>$.

Okiro, K 2014, 'Corporate governance, capital structure, regulatory compliance and performance of firms listed at the East African community securities exchange', University of Nairobi.

Peters, G \& Bagshaw, K 2014, 'Corporate Governance Mechanisms and Financial Performance of Listed Firms in Nigeria: A Content Analysis', Global Journal of Contemporary Research in Accounting, Auditing and Business Ethics (GJCRA), vol. 1, no. 2, pp. 103-28.

Pfeffer, J \& Salancik, GR 2003, The external control of organizations: A resource dependence perspective, Stanford University Press.

Porter, ME 2008, Competitive advantage: Creating and sustaining superior performance, Simon and Schuster.

Radebaugh, LH, Sullivan, DP \& Daniels, JD 2015, International business: Environments and operations, Pearson Education.

Rossi, M, Nerino, M \& Capasso, A 2015, 'Corporate governance and financial performance of Italian listed firms. The results of an empirical research', Corporate Ownership and Control, vol. 12, no. 2, pp. 628-43.

RSE 2015, Rwanda Stock Exchange, listed Securities viewed 15 october 2016, <http://www.rse.rw/listedsecurities/>.

Salvatore, D 2004, International economics, Willey International Edition, USA.

Schellenger, MH, Wood, DD \& Tashakori, A 1989, 'Board of Director Composition, Shareholder Wealth, and Dividend Policy', Journal of management, vol. 15, no. 3, pp. 457-67.

Shah, R, Haldar, A \& Rao, SVDN 2014, 'Economic value added: A financial flexibility tool', Corporate Ownership and Control, vol. 12, no. 1CONT8, pp. 703-8.

Shapiro, SS \& Wilk, MB 1965, 'An analysis of variance test for normality (complete samples)', Biometrika, vol. 52, no. 3/4, pp. 591-611.

Shleifer, A \& Vishny, RW 1997, 'A survey of corporate governance', Journal of Finance, vol. 52, no. 2, pp. 737 83.

Siddiqui, SS 2015, 'The association between corporate governance and firm performance - a meta-analysis', International Journal of Accounting \& Information Management, vol. 23, no. 3, pp. 218-37.

Siwadi, P, Miruka, C \& Ogutu, FA 2015, 'The impact of corporate governance on firm performance in the Zimbabwean manufacturing sector', Corporate Ownership and Control, vol. 12, no. 4Cont7, pp. 779-90.

Soliman, MM, Ragab, AA \& Eldin, MB 2014, 'Corporate governance structure and firm' financial performance: Evidences from Egypt', Corporate Board: Role, Duties and Composition, vol. 10, no. 1, pp. 49-59.

Tabachnick, BG \& Fidell, LS 2006, Using multivariate statistics, 5 edn, Pearson.

Tabachnick, BG, Fidell, LS \& Osterlind, SJ 2001, Using multivariate statistics, 4th edn, Needham Heights, MA: Allyn \& Bacon.

Tilling, MV 2004, 'Some thoughts on legitimacy theory in social and environmental accounting', Social and Environmental Accountability Journal, vol. 24, no. 2, pp. 3-7.

USE 2014, The Background of the Uganda Securities Exchange (USE), viewed 10, October 2016, $<$ https://www.use.or.ug/content/background $>$. 
Veal, AJ 2005, Business research methods: a managerial approach / A.J. Veal, South Melbourne: Pearson Addison Wesley, 2005 2nd ed.

Waduge, DSLCS 2011, 'Governance and performance: an empirical study of Australian universities', Victoria University.

Watson, PK \& Teelucksingh, SS 2002, A practical introduction to econometric methods: Classical and modern, University of West Indies Press.

Weber, Y, Tarba, S, Stahl, G \& Rozen Bachar, Z 2012, 'Ingenuity in international mergers and acquisitions: A test of new integration approach paradigm', Handbook of research on mergers and acquisitions. Cheltenham: Edward Elgar.

Weir, C, Laing, D \& McKnight, PJ 2002, 'Internal and external governance mechanisms: their impact on the performance of large UK public companies', Journal of Business Finance \& Accounting, vol. 29, no. 5 - 6, pp. 579-611.

Williamson, OE 1985, 'Assessing contract', Journal of Law, Economics, \& Organization, vol. 1, no. 1, pp. 177208.

1988, 'Corporate finance and corporate governance', The journal of Finance, vol. 43, no. 3, pp. 567-91.

Yabara, M 2012, 'Capital market integration: progress ahead of the east african community monetary union', IMF Working Paper, no. 12/18.

Youssef, A \& Bayoumi, M 2015, 'Investigating the relationship between corporate governance and banks' financial performance: Egypt case', Corporate Ownership and Control, vol. 13, no., pp. 817-30.

Zagorchev, A \& Gao, L 2015, 'Corporate governance and performance of financial institutions', Journal of Economics and Business, vol. 82, pp. 17-41.

Zikmund, W, Babin, B, Carr, J \& Griffin, M 2012, Business research methods, Cengage 